\title{
The effectiveness of detached mindfulness on perceived stress and sleep quality in patients with COVID-19
}

\author{
Arezoo Ghasem Khanloo ${ }^{1}$, Vahid Sabri ${ }^{2}$, Mohsen Madadloo ${ }^{1}$ \\ 1-M.A, Department of Health, Khoy University of Medical Sciences, Khoy, Iran. \\ 2- PhD, Department of Health, Khoy University of Medical Sciences, Khoy, Iran. \\ Corresponding Author: Arezoo Ghasem Khanloo E-mail: Psy.arezoo@gmail.com
}

Received: 30/09/2021

Accepted: 14/12/2021

\begin{abstract}
Introduction: Patients with Covid-19 experience high levels of stress and low sleep quality due to treatment isolation.

Aim: The aim of this study was to investigate the effect of faulty mindfulness on perceived stress and sleep quality in patients with Covid-19.

Method: The research method was quasi-experimental with pre-test and post-test design with control group. The statistical population was all patients with Covid-19 in Khoy in 2021. From the list of people with positive molecular diagnosis test, 30 patients were purposefully selected, then randomly divided into experimental and control groups. Data were collected using Perceived Stress Questionnaire (PSS) and Sleep Quality Questionnaire (PSQI) in pre-test and post-test and then analyzed using multivariate analysis of covariance in SPSS-26 software.

Results: The results show that the detached mindfulness between the two groups has a significant difference in the amount of perceived stress with $F=38.69$ at the level of 0.001 and sleep quality with $\mathrm{F}=59.36$ at the level of 0.001 ; The magnitude of the effect of faulty mindfulness was obtained to reduce perceived stress (0.59) and improve sleep quality (0.50).

Conclusion: Covid-19 is associated with a range of widespread psychological symptoms such as stress, depression and sleep problems. Based on the findings of the study, it can be concluded that detached mindfulness can reduce patients' perceived stress and improve the sleep quality of patients. Therefore, the implementation of psychological intervention programs can prevent the continuation of psychological problems in patients.
\end{abstract}

Keywords: Detached mindfulness, Sleep quality, Stress, Covid-19

How to cite this article: Ghasem Khanloo A, Sabri V, Madadloo M. The effectiveness of detached mindfulness on perceived stress and sleep quality in patients with COVID-19. Shenakht Journal of Psychology and Psychiatry. 2022; 8 (6): 10-23 .URL: http://shenakht.muk.ac.ir/article1-1276-en.pdf

Copyright $(\odot 2018$ the Author (s). Published by Kurdistan University of Medical Sciences. This is an open access article distributed under the terms of the Creative Commons Attribution-Non Commercial License 4.0 (CCBY-NC), where it is permissible to download, share, remix, transform, and buildup the work provided it is properly cited. The work cannot be used commercially without permission from the journal. 


\title{
تأثير تكنيكهاى ذهن آكاهى كسليله بر روى استرس ادراك شله و كيفيت خواب بيماران مبتلا به كوويد-19
}

\author{
آرزو قاسم خانلو'، وحيد صبرى '، محسن مددلو' \\ ا. كارشناسى ارشد، معاونت بهداشت، دانشگاه علوم يز شكى خوى، خوى، ايران.

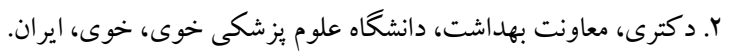

مولف مسئول: آرزو قاسم خانلو ايميل: Psy.arezoo@gmail.com

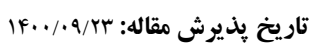

تاريخ دريافت مقاله:

جكيده

مقدمه: بيمار ان مبتلا به كوويد-19 سطح بالايى از استرس و كيفيت خواب پايين را به دليل مجزا سازى درمان تجربه مى كنند. هدف: يُزوش حاضر با هدف بررسى تأثير ذهن آكاهى گسليده بر روى استرس ادراكك شده و كيفيت خواب بيماران مبتلا به كوويد-19 انجام شد.

روش: روش بزوهش نيمه آزمايشى با طرح بيش آزمون و بس آزمون با گروه گواه بود. جامعه آمارى كليه بيماران مبتلا به كوويد-19

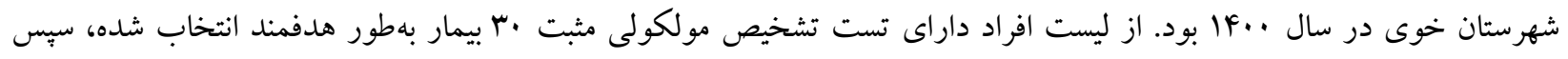

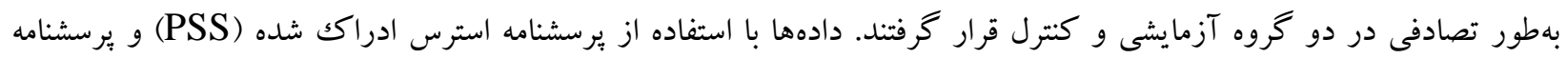

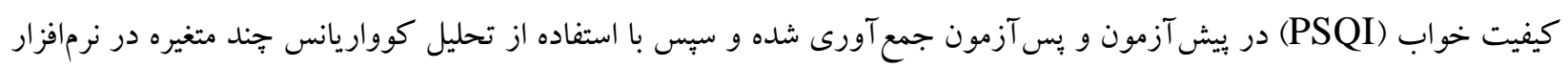
نسخه צY مورد تجزيه و تحليل قرار كرفتند. SPSS

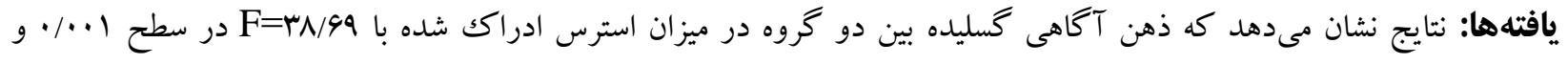

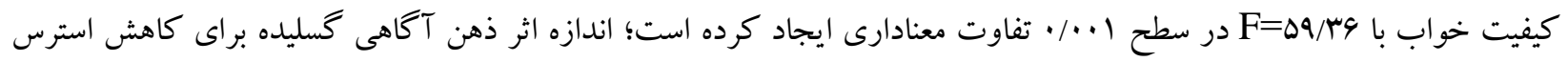

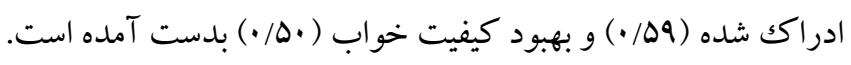

نتيجه كيرى: براساس يافته هاى نتايج بثزوهش مىتوان نتيجه گرفت كه ذهن آكاهى كسليده مىتواند استرس ادارك شده بيماران را

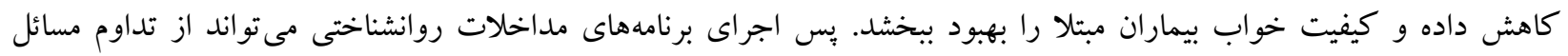
روانشناختى در بيماران جلو گيرى به عمل آورد.

كليدوازهها: ذهن آكاهى گسليده، استرس، كيفيت خواب، كوويد-19 
به كوويد-19 ممكن است احساس تنهايى، عصبانيت،

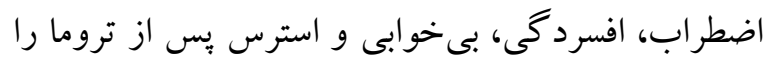

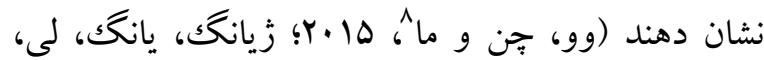

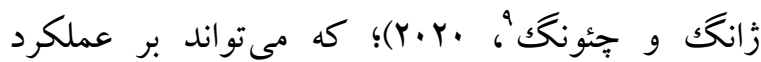
اجتماعى و شغلى و كيفيت زندكى افراد تأثير منفى

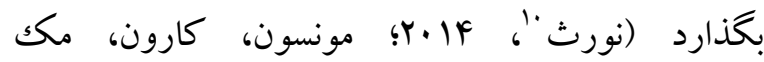

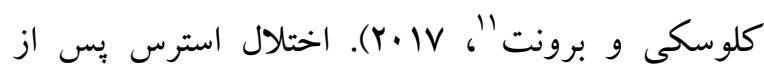

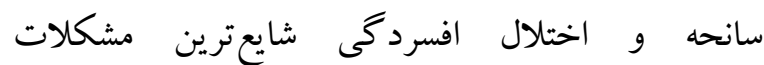
روانشناختى طولانى مدت براى زمان إيدمى سارس بود

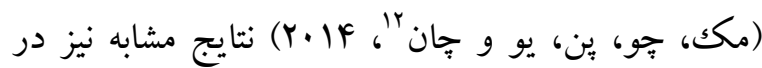

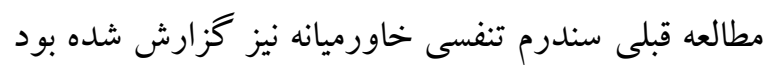

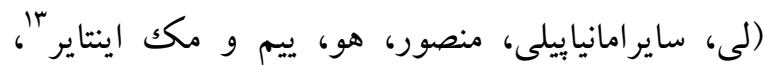

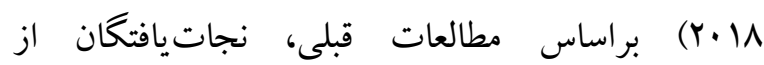
بيمارىهاى عفونى ويروسى مستعد ابتلا به افسردگى بركئ

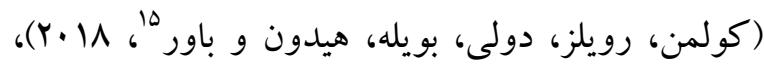

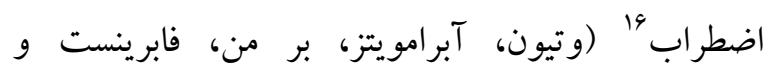

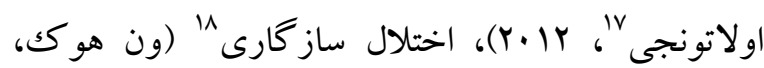

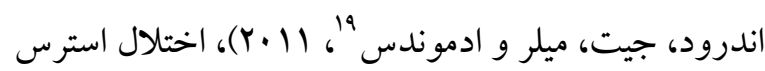

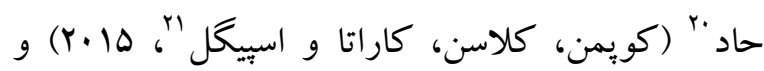

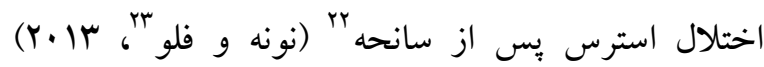
هستند. مطالعه بررسى اثرات روانشناختى در طى شيوع

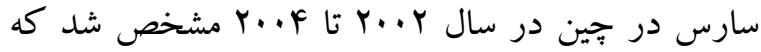

8- Wu, Chan \& Ma

9- Xiang, Yang, Li, Zhang, Zhang \& Cheung

${ }^{10}$ - North

11. Monson, Caron, Mc Closkey \& Brunet

12 - Mak, Chu, Pan, Yiu \& Chan

${ }^{13}$ - Lee, Subramaniapillai, Brietzke, Mansur, Ho, Yim \& McIntyre

${ }^{14}$ - Depression

15- Kuhlman, Robles, Dooley, Boyle, Haydon \& Bower

16 - Anxiety

17 - Wheaton, Abramowitz, Berman, Fabricant \& Olatunji

18 - Adjustment disorder

19. Van Hoek, Underwood, Jit, Miller \& Edmunds

${ }^{20}$ - Acute stress disorder

${ }^{21}$ - Koopman, Classen, Cardena \& Spiegel

22 - Post traumatic stress disorder

23 - Noone \& Flu

\section{مقدمه}

ويروس كرونا' خانواده بزرگى از ويروسها هستند كه موجب ابتلا به طيف وسيعى از عفونتهاى دستگاه تنفسى در انسان مىشوند؛ كه از سرماخوردگى تا ابتلا به بيمارىهاى شديد تنفسى مثل سندرم تنفسى خاورميانه و و

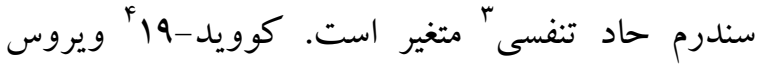
نوظهور و بيمارى ناشى از آن قبل از طغيان در ووهان ناشناخته بود. در دسامبر سال 19 +ץ بيمارى كوويد-19 در ووهان جين ظاهر شد بهطورى كه در عرض جند ماه به تمام كشورهاى جهان با سرايت بالا منتقل شد و در اواخر اسفند نمونههاى اوليه در ايران شناسايى شدند بهطورى كه تا اواخر اسفند شرايط اضطرارى در كشور برقرار كرديد. سازمان بهداشت جهانىه هاعلام كرده كه شيوع كوويد19 يكك مسئله اورزانس بهداشت عمومى جهانى است. نهفتخى اين ويروس جديد ال| روز است. تب، سرفه خشك و خستكى علائم بالينى

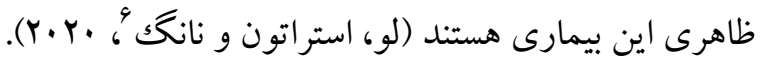
منابع عفونت ديده شده عمدتاً از طريق قطرات تنفسى و تماس نزديكك با فرد بيمار منتقل مىشوند. (ليو، جن،

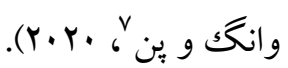

براساس دستورالعملهاى درمانى بيماران كوويد-19 نياز

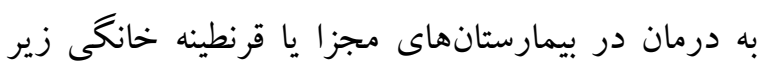
نظر يزشك دارند. به دليل محيط ايزوله و انزواى اجتماعى، خطر ادراكك شده، عدم اطمينان، ناراحتى جسمى، عوارض جانبى داروها، ترس از انتقال ويروس به ديخران و اخبار منفى در شبكههاى اجتماعى بيماران مبتلا

1. Corona virous

2. The Middle East respiratory syndrome (MERS)

3 - Severe acute respiratory syndrome (SARS)

4 - Covid-19

5 - World Health Organization

6. Lu, Stratton \& Tang

7. Liu, Chen, Wang \& Pan 
هاى منظم درباره مشكلات روانشناختى براى تسريع روند بهبودى بيماران از اهميت بسزايى برخوردار است تا از احساس ناتوانى، اضطراب، مشكلات خواب، انزوا، يرخاشخرى و تحريك يذيرى جلو گيرى به عمل آيد.

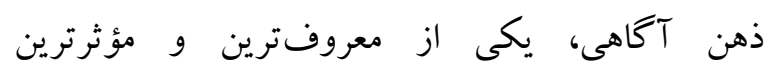
تكنيكهاى رسيدن به آرامش و كنترل استرس است. ذهن آكاهى گسليده راهبردهايى به بيمار مىدهد تا رهيل خودش را از مكانيسمهايى كه موجب قفل شدن در يردازش به صورت نخرانى، نظارت بر تهديد و و خود كنترلى ناساز گارانه مىشود رها كند و با آموزش لهرد يردازش انعطاف يذير هيجانى طرح و برنامهاى رادر آينده براى راهنمايى تفكر و رفتار در مواجهه با تهديد و آسيب

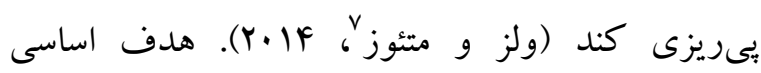
خود كنترلى و خودآموزى است تا فراگيران يادگيرند كان مستقلى شوند كه بتوانند فر آيندهاى شناختى ياد گيرىشان را در جهت اهداف تعيين شده خود هدايت، نظارت و اصلاح كنند (ولز و همكاران، IF) متعددى اثربخشى فراشناخت درمانى و ذهن آكاهى كسليده را در اختلالات مختلف روانى تائيد كردهاند.

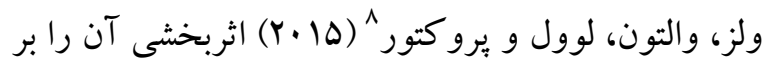
بر روى افراد افسرده مورد يُزوهش قرار دادند و نتايج بهبودى فراوانى را در دوره مداخله و ييگيرى نشان مى داد. همجينين قويدل و موسى زاده (هوس|) نشان دادند

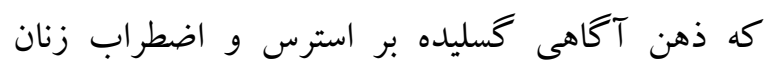
نابارور نيز مؤثر واقع شده است. با توجه به اينكه بيماران مبتلا به كوويد -19 استرس بالايى را تجربه مىنمايند و در برخى موارد ترس از تشديد شرايط نيز در اين بيماران

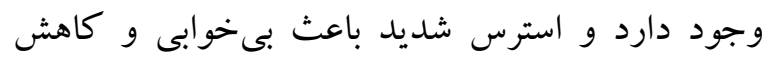

7. Mathews

${ }^{8}$ - Wells, Walton, Lovell \& Proctor
بلافاصله شيوع اضطراب و افسردگى بهطور برجسته شيوع

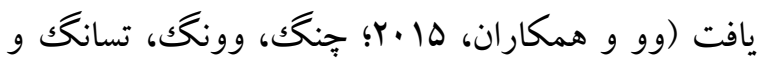

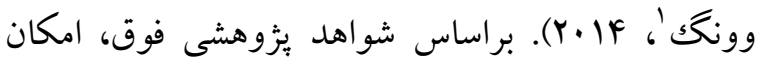
دارد در زمان ابيدمى كوويد-19 نيز وضعيت روانى مردم و بيماران تحت تأثير قرار بخيرد. با توجه به شرايط اورزانسى فعلى اين بيمارى قابل بيشبينى است كه برخى

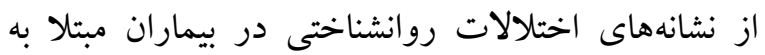
كوويد-19 بروز نمايد. نتايج يثوهشهاى مختلف بر روى بيماران مبتلا به كوويد-19 در كشور جين نشان مىدهد كه برخى از اختلالات روانشناختى مانند اضطراب، ترس، افسردگى، تغييرات هيجانى، بىخوابى و اختلال استرس پس از سانحه با درصد شيوع بالا در اين

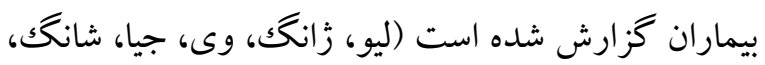

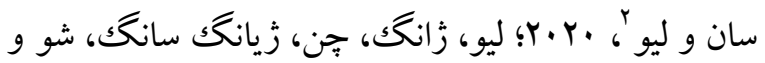

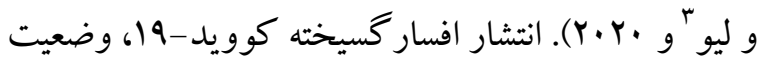
وضعيت نامطلوب بيماران ايزوله شده در بخش مراقبتهاى ويزه و با مشكل حاد تنفسى، عدم وجود يكك درمان دارويى مؤثر و درنهايت مرككومير ناشى از اين بيمارى از فاكتورهاى مهم مؤثر بر سلامت روان افراد

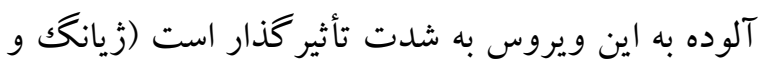
همكاران، ·r.r.r! ليما، همداح، ويلموت، بيرس، شاه،

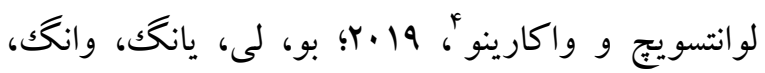

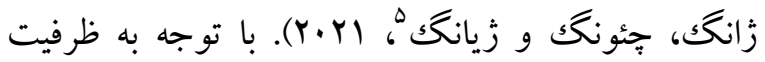
تحمل روانشناختى بايين، اين بيماران به شدت در معرض بروز اختلالات روانشناختى قرار دارند (بايى، يائو، وى،

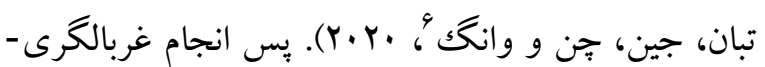

\footnotetext{
1- Cheng, Wong, Tsang \& Wong

2- Liu, Zhang, Wei, Jia, Shang, Sun \& Liu

3 - Liu, Zhang, Chen, Xiang, Song, Shu \& Liu

4. Lima, Hammadah, Wilmot, Pearce, Shah, Levantsevych \& Vaccarino

5- Bo, Li, Yang, Wang, Zhang, Cheung \& Xiang

${ }^{6}$ - Bai, Yao, Wei, Tian, Jin, Chen \& Wang
} 
بسترى در بيمارستان و نياز به دارودرمانى براى مشكلات

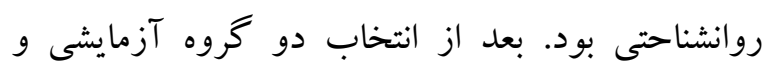
كنترل و كسب رضايت آكاهانه از هر دو كروه، بيش آزمون با استفاده از ابزارهاى بُزوهشى بعد از هماهنكى صورت گرفته با بيماران توسط بزوهشخر اخذ گرديد. سبس در كروه آزمايشى ه جلسه ها دقيقه اى آموزش روانشناختى درباره مشكلات روانشناختى كوويد-19 و آموزش تكنيكهاى ذهن آكاهى گسليده انجام گرفت. براى گروه كنترل هيج نوع مداخلهاى انجام نشد. در حين اجراى يزوهش ب نفر در گروه آزمايشى همكارى لازم را براى اتمام جلسات نداشتند كه از يزوهش كنار كذاشته شده و با بيماران ديخر جايخزين شدند. درمان توسط كارشناس ارشد روانشناسى بالينى صورت مى كرفت كه سابقه V سال روان درمانى در مراكز خدمات جامع سلامت دارد و ارزيابى اوليه و آخر درمان به صورت لينك يرسشنامه طراحى شده در گو گل فرم صورت كرفته است. دادهها بعد از جمع آورى و وارد كردن در نرمافزار SPSS نسخه צrك، با استفاده از آزمونهاى آمارى توصيفى مثل ميانگين و انحراف استاندارد و آزمونهاى استنباطى تحليل كوواريانس جند متغيره مورد تجزيه و تحليل قرار گرفتند. برنامه درمانى تكنيككهاى ذهن آكاهى كسليده از كتاب درمان فراشناختى ولز (ه) (1ه) در ه جلسه طراحى شده است و اعتبار و يايايى آن نيز مورد تائيد قرار خرفته است كه در بزّوهش حاضر نيز از يروتكل حاضر استفاده شد كه موضوعات و محتواى جلسات درمانى در جدول آمده است.
كيفيت خواب اين بيماران مىشود. با توجه به اينكه يثزوهشهاى مختلف مطرح شده، تأثير ذهن آكاهى كسليده بر روى متغيرهاى مختلف روانشناختى مثل

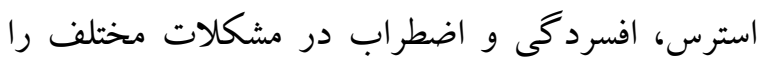
تائيد كردهاند، بزوهش حاضر به دنبال باسخكويى به اين سؤال است كه آيا ذهن آكاهى گسليده بر روى استرس ادراكك شده و كيفيت خواب بيماران مبتلا به كوويد-19 نيز تأثير دارد؟

\section{روش}

يُؤهش حاضر بهعنوان يك كار آزمايى بالينى نيمه تجربى

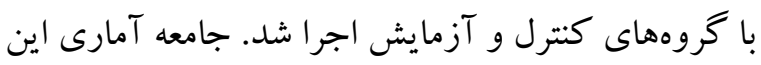
مطالعه را كليه بيماران هاه-11 ساله مبتلا به كوويد-19 شهرستان خوى تشكيل دادند كه در فاصله زمانى

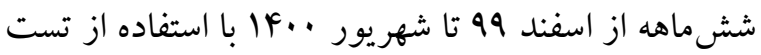
تشخيصى مولكولى' 'تشخيص كوويد-19 دريافت كرده و داراى علائم و مشكلات روانشناختى بودند. از ليست بيماران مبتلا به كوويد-19 داراى مشكلات روانشناختى • ب بيمار براساس معيارهاى ورود و خروج انتخاب شده و. به طور تصادفى به دو گروه ها نفرى كنترل و آزمايش تقسيم شدند. ملاككهاى ورود براى بئوهش شامل، تشخيص كوويد-19 با استفاده از تست تشخيص

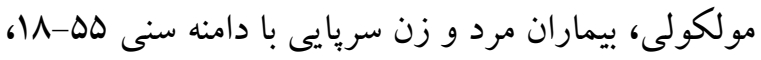
عدم ابتلا به هر گونه اختلال روانبريشى در سابقه قبلى، عدم مصرف داروهاى روانيزشكى، عدم ابتلا به سوءمصرف مواد، رضايت و موافقت شركت كنند گان، سطح تحصيلات حداقل دييلم و ملاككهاى خروج نيز شامل، ناتوانى در صحبت كردن به خاطر مشكلات دوره

\footnotetext{
'- Polymerase Chain Reaction
} 


\begin{tabular}{|c|c|}
\hline محتواى جلسه & جلسه \\
\hline شر كت در جلى استرس و كيفيت خواب فرد، بيان هدف آموزش روانى درباره كرونام واسترس، بيان مطالبى درباره تلفنى، اخذ رضايت برامه درمانى & اول - اول \\
\hline كسليده و آموزش تكاليف خانگى و بحث درباره افكار و هيجانات و شروع بحث درباره ذهن آكاهى استعاره ابرها & دوم \\
\hline كلامى & سوم \\
\hline بررسى تكاليف خانكى و آموزش و تمرين سر كوبى فكر و تداعى آزاد & 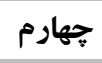 \\
\hline 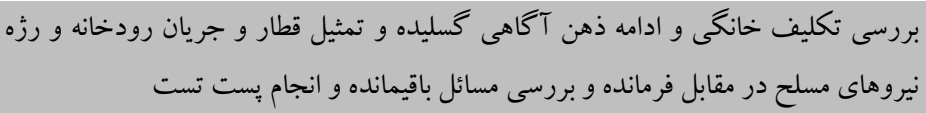 & هنجم \\
\hline
\end{tabular}

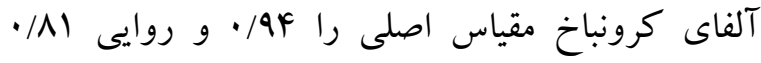

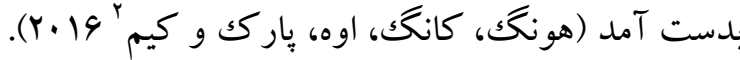

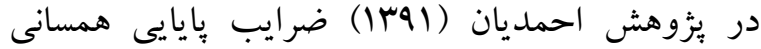
درونى از طريق ضريب آلفاى كرونباخ براى كل نمرات يرسشنامه AF/ • مشخص گرديد. همجنين با استفاده از روش تحليل مواد ضرايب همبستكى بدست آمده براى مواد مقياس ادراكك استرس ادراكك شده كل در دامنهى

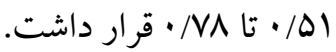

\section{يرسشنامه كيفيت خواب لتيززبوركى" (PSQI): اين} يرسشنامه را دكتر بويس و همكاران (1919) در موسسه روانيزشكى يترزبورگك طراحى كردند. كل برسشنامه 19 آيتم دارد كه در طيف ليكرت \& درجهاى از · تا م نمره گذارى شده است و V زير مقياس كيفيت ذهنى خواب، تأخير به خواب رفتن، مدت زمان خواب، ميزان بازدهى خواب، اختلالات خواب، استفاده از داروهاى خوابآور و اختلال عملكردى روزانه را ارزيابى مى كند. ضريب همسانى درونى اين برسشنامه در يك بررسى بر روى جمعيت اسبانيايى ه·A/· به دست آمده و ضريب باز آزمايى آن NV · بود و همبستگى آن با يرسشنامه

${ }^{2}$ - Hong, Kang, Oh, Park \& Kim

${ }^{3}$ - Pittsburgh Sleep Quality Index
يرسشنامه استرس ادراك شله ' (PSS-10): اين يرسشنامه توسط كوهن، كامارك و مرملستين (r| •r) ساخته شده است. نسخهاى كه در بثزوهش حاضر از آن استفاده شده است نسخه •إؤالى است كه هر آيتم براساس يك طيف ليكرت ه درجهاى ("هيج)؛؛ ("كم)؛؛ (امتوسط) ؛ ((زياد)؛ (اخيلى زياد)) پِاسخ داده مىشود از اين برسشنامه

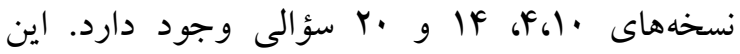
برسشنامه براى استفاده در نمونهاى عادى با حداقل تحصيلات ساخته شده است. فهم جملات ساده بوده و

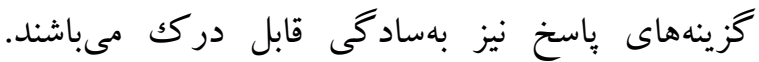
همجنين ياسخها نيز يكك ماهيت كلى دارند و از اينرو، نسبتاً از هركونه محتواى خاصى كه ويزه يكك زيرگروه معين باشند، مبرا هست. در اين برسشنامه ياسخدهند نظر خود را درباره غيرقابل كنترل بودن، يِيشينىنايذيرى و مشقتبار بودن زندگى خويش بيان مى كنند. سؤالهاى اين يرسشنامه درباره احساسات و افكارى طرح شدهاند

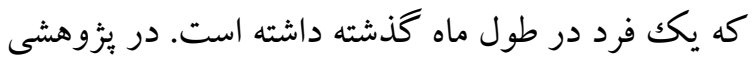
بر روى افر اد بزر گسال كره جنوبى صورت گرفت ضره

\footnotetext{
1- Perceived stress questionnaire
} 
كارشناسى و 9 درصد هم تحصيلات تكميلى بودند. ميانگين سنى بيماران در گروه آزمايش سال و در گروه كنترل $9 \Lambda$ / توصيفى ميانگين و انحر اف استاندارد آزمودنىها بثزوهش در متغيرهاى استرس ادراكك شده، كيفيت ذهنى خواب، تأخير در به خواب رفتن، طول مدت خواب، كفايت خواب، اختلالات خواب، مصرف دارو، اختلال در عملكرد روزانه و كيفيت ذهنى خواب و نمره كلى كيفيت خواب به تفكيك در گروههاى آزمايشى و كنترل در

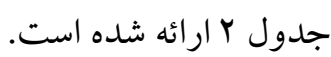

كيفيت زندگى براى بررسى روايى اVI/· بدست آمده

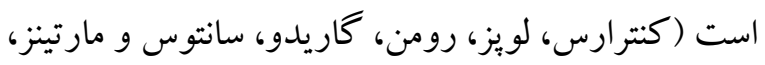

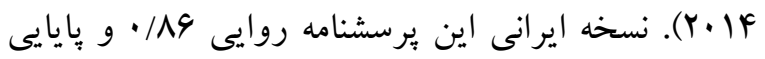

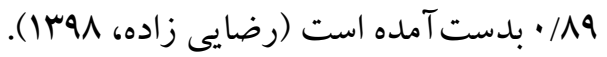

\section{يافتهها}

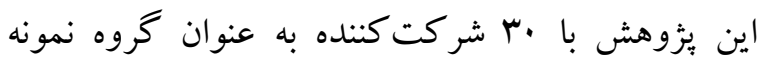

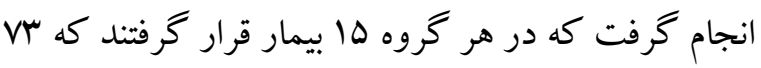

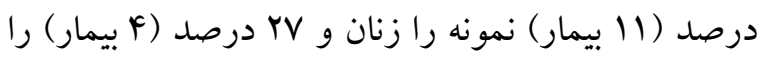
مردان تشكيل دادند. r ب درصد از گروه نمونه آمارى مورد مطالعه بيماران داراى تحصيلات تكميلى زير دييلم، Y Y درصد داراى تحصيلات دييلم، اس درصد تحصيلات

جدول r آمارههاى توصيفى براى كروه كنترل و آزمايش در ييش آزمون و پِ آزمون

\begin{tabular}{|c|c|c|c|c|c|}
\hline \multicolumn{2}{|c|}{ كنترل } & \multicolumn{2}{|c|}{ آزمايش كروه } & \multirow[t]{2}{*}{ آزمون مرحله } & \multirow[t]{2}{*}{ متغير } \\
\hline انحر اف معيار & ميانكين & انحراف معيار & ميانگين & & \\
\hline$r / v \wedge$ & $19 / 09$ & $F / \Delta 9$ & IN/AD & ي ييش آزمون & استرس ادراك شده \\
\hline$r / 4 \Lambda$ & $10 / r \Delta$ & T/VA & $\mid F / Y \Delta$ & يس آزمون & \\
\hline $1 / \Gamma$ & $1 / \pi F$ &.$/ 94$ & $1 / r \Delta$ & بيش آزمون & كيفيت ذهنى خواب \\
\hline.$/ 99$ & $1 / 1 F$ & $\cdot / M$ & ·/Ar & يس آزمون & \\
\hline$\cdot / 90$ & $1 / .9$ & $\cdot / \wedge \Delta$ & $1 / 19$ & بيش آزمون & تأخير در به خواب رفتن \\
\hline .199 & $1 / 1 r$ & $\cdot / V 9$ &.$/ 99$ & يس آزمون & \\
\hline . $/ A r$ & $1 / 19$ &.$/ 90$ & $1 / I V$ & ي بيش آزمون & مدتزمان خواب \\
\hline$\cdot / \mathrm{VA}$ & $1 / \cdot r$ & - /AF & $\cdot / \mathrm{Vq}$ & يس آزمون & \\
\hline$\cdot 109$ & $\cdot / \mathrm{AV}$ & .199 & $\cdot / \wedge 9$ & ي يش آزمون & كارايى خواب \\
\hline .191 & $\cdot / \mathrm{VV}$ & $\cdot / \mathrm{VA}$ & $\cdot / \Delta \Delta$ & يس آزمون & \\
\hline .191 &.$/ 99$ & $\cdot / \wedge \Delta$ & $1 / 1 r$ & ي بيش آزمون & اختلالات خواب \\
\hline$\cdot / 19$ & $\cdot / N \Delta$ & $\cdot / 4 \Delta$ & ·/A4 & 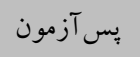 & \\
\hline$\cdot / \mathrm{VA}$ & $\cdot / v \Delta$ & $\cdot / v \Delta$ &.$/ 9 \mathrm{~V}$ & يشي آزمون & مصرف داروهاى خوابآور \\
\hline .190 & $\cdot / v \wedge$ & .190 & $\cdot / 4 \wedge$ & 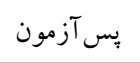 & \\
\hline$\cdot / 19$ & $1 / 19$ & .190 & $1 / 11$ & بيش آزمون & عملكرد نامناسب \\
\hline .199 & $1 / \cdot 1$ &.$/ 09$ & .194 & 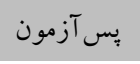 & \\
\hline$r / 4 r$ & $V / \pi q$ & r/TD & $V / \& V$ & ي يش آزمون & نمره كلى \\
\hline$r / 19$ & $9 / 99$ & $r / r \Lambda$ & $F / A r$ & ״ֶس آزمون & \\
\hline
\end{tabular}


است كه براى بررسى بيشتر از آزمون تحليل كوواريانس

استفاده شده است. در جدول ب مفروضات آزمون تحليل كوواريانس شامل نرمال بودن دادهها و همخنى واريانس بررسى شده است.
به طور كلى جدول r نشان مىدهد كه ميانگين نمرات بس آزمون در كروه آزمايش نسبت به نمرات بس بـ آزمون در خرده مقياسهاى كيفيت خواب و استرس ادراكك شده در كروه كنترل كاهش بيشترى داشته است؛ كه براى بررسى بيشتر نيازمند استفاده از آزمون آمارى استنباطى

\begin{tabular}{|c|c|c|c|c|}
\hline \multicolumn{2}{|c|}{ كروه كنترل } & \multicolumn{2}{|c|}{ تروه آزمايش } & \multirow[t]{2}{*}{ متغير } \\
\hline سطح معنى دارى & $\mathbf{Z}$ & سطح معنى دارى & $\mathbf{Z}$ & \\
\hline$\cdot / r$ &.$/ 14$ & $\cdot / r$ & $\cdot / M r$ & استرس ادراكى شده \\
\hline$\cdot / r$ &.$/ 14$ & $\cdot / 10$ & $\cdot / 1 \wedge$ & كيفيت ذهنى خواب \\
\hline.$/ 19$ & . & $\cdot / \cdot 1$ & .110 & تأخير در به خواب رفتن \\
\hline 111 &.$/ 10$ & $\cdot / \cdot V$ & $\cdot / 10$ & مدت زمان خواب \\
\hline 19 & $M \Lambda$ & $\cdot / l r$ & .119 & كارايى خواب \\
\hline$\cdot / \mathrm{VV}$ & .119 & $\cdot / 91$ & $\cdot / / V$ & اختلالات خواب \\
\hline .119 & .119 & $\cdot 109$ & $\cdot / 1 \wedge$ & مصرف داروهاى خوابآور \\
\hline.$/ 19$ &.$/ 1 \mathrm{~V}$ & .191 & /Ir & عملكرد نامناسب \\
\hline$\cdot / r$ &.$/ 1 F$ & $\cdot / l F$ & $\cdot / l f$ & نمره كلى \\
\hline
\end{tabular}

بودن دادهها، براى بررسى همخنى واريانس ها در دو گروه نتايج جدول r نشان مىدهد فرضيه نرمال بودن دادهها آزمايشى و كنترل از آزمون لون استفاده گرديده است، بردئ تائيد شده است جون نتايج آزمون كولموگرافنتايج بدست آمده از آن در جدول \& كز ارش شده است. اسميرنف در سطح ه•/ • معنادار نبودند و بدين معنى است كه دادهها نرمال هستند. بعد از تائيد فرضيه نرمال

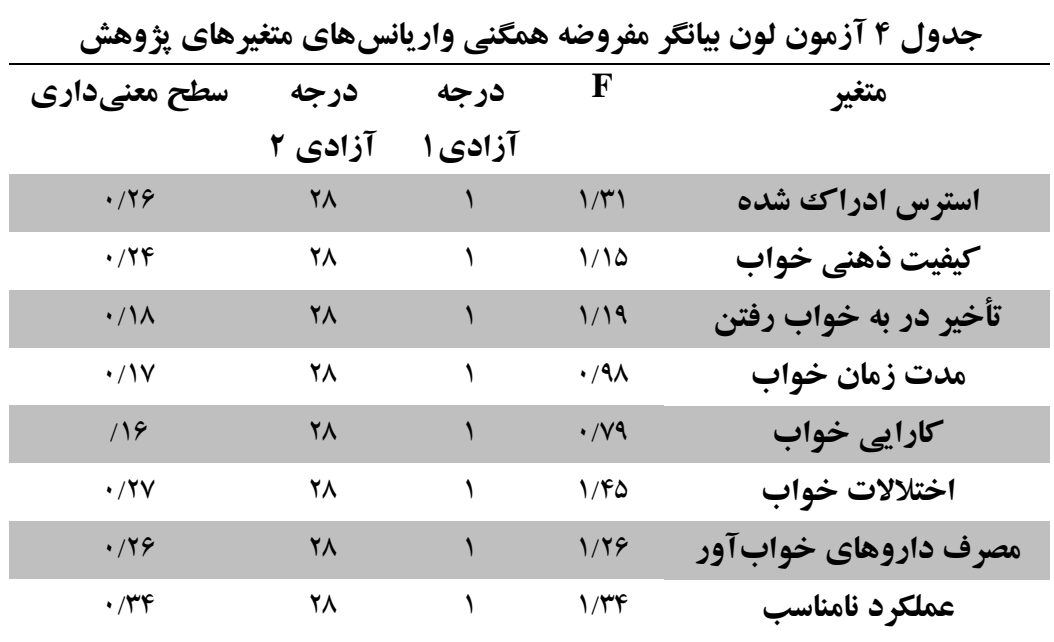




\section{$\cdot / 49$ \\ rA \\ $1 \quad 1 / 49$ \\ نمره كلى}

جدول ها بهمنظور بررسى اينكه آيا تفاوتهاى ايجاد شده

نتايج جدول \& نشاندهنده فرضيه همخنى واريانسها است از نظر آمارى نيز معنادار است و آيا مداخله درمانى مورد جون مقدار معنادارى آزمون لون براى همه متغيرهاى استفاده باعث ايجاد اين تفاوتها شده است، از آزمون يثزوهش بالاتر از ه•/ تحليل كوواريانس استفاده شد. واريانسها براى انجام تحليل كوواريانس برقرار است. در

جدول ه نتايج تحليل كوواريانس تك متغيره

\begin{tabular}{|c|c|c|c|c|c|c|}
\hline اندازه & معنى سطح & $\mathbf{F}$ & مجذانكين & آزادى درجه & مجذورات & متغير \\
\hline$\cdot 109$ &.$/ .1$ & $99 / \% 1$ & $\Delta r / r \Lambda$ & 1 & rN/Dr & استرس ادراكت شده \\
\hline$\cdot / \Delta F$ &.$/ \cdot 1$ & $r Q / V I$ & $r q / r \Delta$ & 1 & $r q / r \Delta$ & كيفيت ذهنى خواب \\
\hline.$/ 94$ &.$/ \cdot .1$ & $r V / Q \Lambda$ & $G Y / F V$ & 1 & $G Y / q V$ & تأخير در به خواب رفتن \\
\hline$\cdot / 01$ &.$/ \cdot 1$ & rN/GF & $49 / 01$ & 1 & $F 9 / 01$ & مدتزمان خواب \\
\hline$\cdot / 4 \wedge$ &.$/ .1$ & KF/MG & $F \mid / Y q$ & 1 & $41 / r q$ & كارايى خواب \\
\hline$\cdot / \Delta$ &.$/ \cdot 1$ & $r v / v \wedge$ & $F \Delta / A F$ & 1 & $F \Delta / A F$ & اختلالات خواب \\
\hline$\cdot / F F$ &.$/ \cdot 1$ & ro/qr & $r 9 / 90$ & 1 & rq/90 & مصرف داروهاى خواب آور \\
\hline$\cdot / \Delta r$ &.$/ \cdot 1$ & FY/YF & $\mathrm{FV} / \mathrm{TV}$ & 1 & $F V / T V$ & عملكرد نامناسب \\
\hline$\cdot / \Delta$ &.$/ \cdot 1$ & $\Delta Q / \mu q$ & $F \Delta / V \Delta$ & 1 & FO/VD & نمره كلى \\
\hline
\end{tabular}

يزوهش حاضر با هدف بررسى تأثير ذهن آكاهى گسليده بر استرس ادراكك شده و بهبود كيفيت خواب انجام شد.

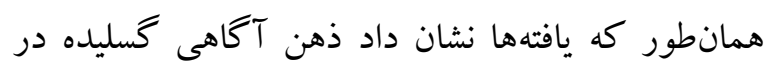
كاهش استرس ادراك شده بيماران مبتلا به كوويد-19 مؤثر واقع شده است كه در راستاى يثوهشهاى مشابه قبلى مبنى بر تأثير ذهن آكاهى بر كاهش استرس ادراكك

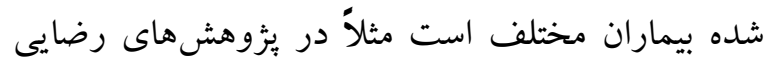

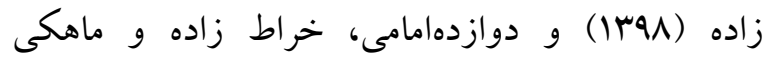

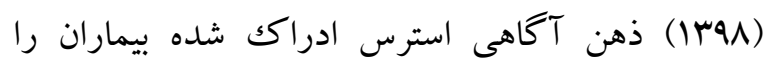
كاهش داده است. آموزش ذهن آكاهى گسليده در از بين بردن يردازشهاى ماندگار و جلو گيرى از تجربه ذهنى افكار مزاحم درباره شرايط بيمارى مفيد هست بردي
نتايج تحليل كواريانس نشان مىدهد كه بين آزمودنىهاى كروه آزمايش و كنترل از لحاظ متغيرهاى وابسته تفاوت

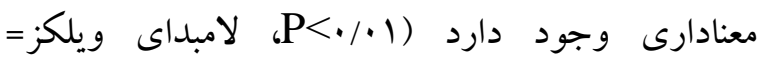
اس/Y/Y). يُ بس براى بى بردن به اين مسئله كه تفاوت بين

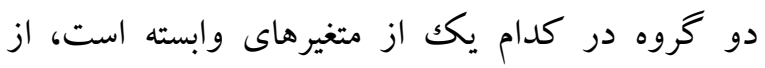
تحليل كوواريانس تكك متغيره استفاده شد. يّ به طور كلى مىتوان نتيجه گرفت كه ذهن آكاهى گسليده بهطور

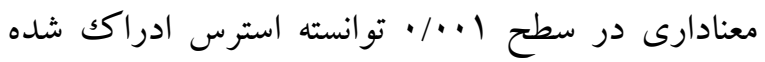
بيماران مبتلا به كوويد-19 را كاهش و كيفيت خواب آنها را بهبود ببخشد. 
همجنين مطالعه حاضر نشان داد كه ذهن آكاهى گسليده بر بهبود كيفيت خواب بيماران مبتلا به كوويد-19 مؤثر است؛ كه همسو با بثزوهش ليو (·.Y.T) هست كه در آن آرامسازى عضلانى به همراه ذهن آكَاهى گسليده كيفيت خواب بيماران مبتلا به كوويد-19 بسترى در بيمارستان را بهبود بخشيده بود. در بزٔوهش بساكك نزاد، آقاجانى و

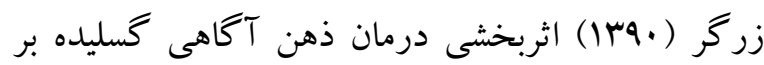
كيفيت خواب و كيفيت زندكى دانشجويان دختر دانشگاه شهيد جمران اهواز را بررسى كرده و نتايج نشان داد كه درمان ذهن آكاهى كسليده به صورت معنادارى كيفيت خواب دانشجويان را با كاهش نشخوار ذهنى و نكرانى كاهش مىدهد. برنامه ^ جلسه درمان ذهن آكاهى كسليده روى افراد دجار بى خوابى، كيفيت خواب آنها را افزايش و تأخير در به خواب رفتن آنها را كاهش داده

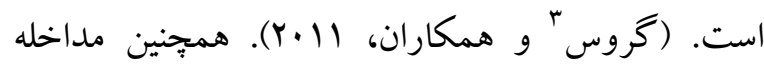
مبتنى بر ذهن آكاهى روى سالمندان نشان داد كه 9 جلسه مداخله استرس، اضطر اب شر كت كنند كان را كاهش داده و كيفيت خواب آنها را بهبود مىبخشد (بلك، اوريلى،

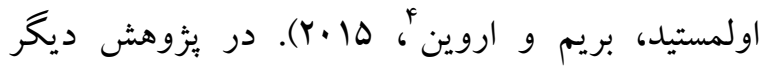
اثربخشى درمان ذهن آكاهى كسليده را بر روى كيفيت خواب سالمندان بالاى VD سال با مشكل بىخوابى را

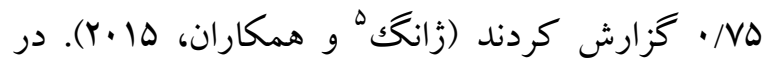
مطالعه يو كك و همكاران (1)

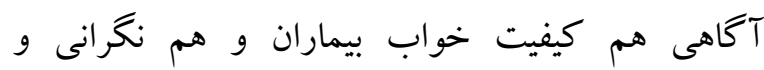
اضطراب آنها را كاهش مىدهد. ذهن آكاهى گسليده مى تواند عوارض بيمارى را كاهش و كيفيت خواب بيماران مبتلا به شكستخى را بهبود ببخشد (زى، دنكَ،

3. Gross

4- Black, O'Reilly, Olmstead, Breen \& Irwin

5- Zhang

6. Yook

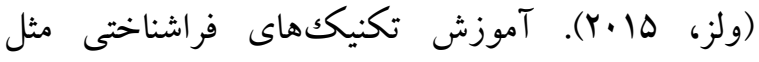
آموزش توجه و ذهن آكاهى گسليده بر سبك زندكى يرستاران شاغل زن متأهل مؤثر بوده و تغييرات قابل توجهى رادر سلامت و ارتقا سبك زندگى به وجود مى آورد (نامنى، شيردل و جهانگيرى، هوبا). همجنين آموزش ذهن آكاهى گسليده مىتواند نقش مهمى در كاهش افسردگى، استرس و علائم جسمانى آن داشته باشد و از عود افسردگى و اضطراب بيشگيرى كند (ستاريور، احمدى و صادقى زاده، هوسا). در مطالعه احمدوند، حيدرى نسب و شعيرى (Y (IM) نيز آموزش

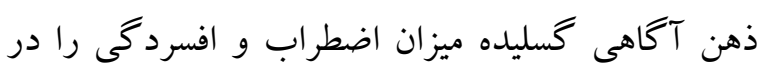
بيماران به طور جشمخيرى كاهش داده است. در بئوهشى آنى درباره تأثير ذهن آكاهى بر كاهش استرس ادارك شده و فشارخون نشان داد كه مداخله ذهن آكاهى مى تواند

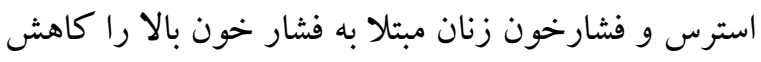
دهد (خسروى و قربانى، هوس1). در مطالعه بانج و اردبيل'

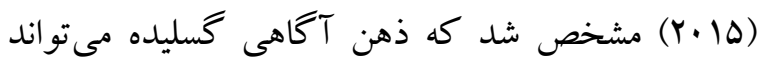
استرس اداركك شده زنان مبتلا به سرطان يِتان را به طور معنادارى كاهش دهد. ذهن آكاهى گسليده و تمرينهاى فيزيكى مىتواند استرس ادراكك شده را بعد از هـ هفته كاهش دهند، همجنين ذهن آكاهى گسليده سلامت روان را با اثرات مثبت تا 4 ماه بعدى بهبود ببخشد (دياز -

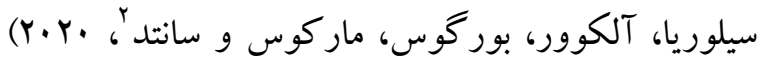
تكنيك هاى ذهن آكاهى گسليده باعث از بين رفتن استرس و پاسخخهاى مقابلههاى غيرارادى مىشود. در اين وضعيت راهبردهاى فراشناختى جديدى شكل مى كيرند كه براى كنار آمدن با افكار مزاحم مفيد هستند (بايى و

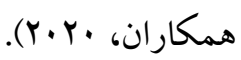

\footnotetext{
1- Banth \& Ardebil

2- Díaz-Silveira, Alcover, Burgos, Marcos \& Santed
} 
كنترل را زنان تشكيل داده بودند. در يزوهشهاى آتى

نقش مردان در نمونهاى مورد مطالعه افزايش بيدا كند.

\section{سياسگز ارى}

در آخر از تمام شر كت كنندهاى كرى امى و واحد سلامت

روان دانشكده علوم يزشكى خوى كه نهايت همكارى را

در اين ئزوهش داشتند، صميمانه تشكر مى كنيم. مقاله

حاضر بركرفته از طرح بثزوهش به كد

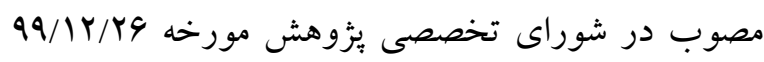

IR.KHOY.REC.1400.003 شناسه اخلاق

دانشكده علوم بزشكى، خدمات بهداشتى و درمانى خوى احلى

صورت گرفته است. هيج گونه تعارض منافعى بين

$$
\text { نويسند كان وجود ندارد. }
$$

\section{References}

Ahmadvand Z, Heydarinasab L, Shairi M. (2012). Prediction of psychological well-being based on the comonents of mindfulness. Joumal of Health Psychology,1 (2), 60-69. (In Persian)

Bai Y, Yao L, Wei T, Tian F, Jin D, Chen L, Wang M. (2020). Presumed asymptomatic carrier transmission of COVID-19. Jama, 323(14), 1406-1407.

Banth S, Ardebil M. (2015). Effectiveness of mindfulness meditation on pain and quality of life of patients with chronic low back pain, Int J Yoga, 8(2), 128-133.

Basaknejad S, Aghajani A, Zargar Y. (2011). The efficacy of mindfulness based cognitive therapy on quality of Life and quality of sleep in girl students. Joumal of Psychology Achievement . 2011; 4(2):181-98. (In Persian)

Black D, O'Reilly G, Olmstead R, Breen, Irwin M. (2015). Mindfulness meditation and improvement in sleep quality and daytime impairment among older adults with sleep disturbances: a randomized clinical trial. JAMA intemal medicine, 175(4), 494-501.
زانگگ، ريجموند، تانگك و زو'، 19 (ب)؛ اما اولين بار است

كه تكنيككهاى ذهن آكاهى گسليده در بيماران مبتلا به كوويد-19 استفاده مىشود. با توجه به شرايط سرايت كنندگى بالاى اين بيمارى و لزوم حفظ انزواى خانكى آموزش تمرينها از راه دور براى كاهش خطرات روانشناختى صورت مى بذيرد. ذهن آكاهى گسليده مى تواند از توليد افكار و هيجانات منفى جلو گيرى كرده و اثرات افزايش فشار عضلانى بر بدن را خنثى نمايد. اين روش همجِنين باعث ايجاد تعادل بين هييوتالاموس خلفى و قدامى مىشود و در نتيجه از بروز عوارض نامطلوب ناشى از تنش جلو گيرى مى كند (غفارى، IrNV )

\section{نتيجه كيرى}

براساس يافتهاى اين يثوهش، آموزش تكنيككهاى ذهن

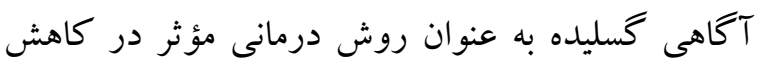
استرس و بهبود كيفيت خواب بيماران مبتلا به كوويد-19 محسوب مىشود. درمانگران و حتى خود بيماران مى تواند با يادكيرى نحوه انجام تكنيككهاى ذهن آكاهى كسليده در كنار دارو درمانى، روند بهبود را تسريع كرده و از مزمن شدن مشكلات روانشناختى جلو گيرى نمايند. ازجمله محدوديتهاى بزّوهش حاضر كه امكان برطرف كردن آن براى بثزوهشخران وجود نداشت آموزش بعد از سه هفته ابتلا به كوويد-19 بود كه بهتر است در يثزوهشهاى آتى با همكارى بيمارستانهاى سانتر ال كرونا در داخل بيمارستان در اوايل ابتلا اين بئوهش صورت بحيرد. محدوديت ديخر بثزوهش تمايل مشاركت زنان براى همكارى بود به همين خاطر اكثريت گروه درمانى و

\footnotetext{
1- Xie, Deng, Zhang, Richmond, Tang \& Zhou
} 
Bo H, Li W, Yang Y, Wang Y, Zhang Q, Cheung T, Xiang Y. (2021). Postraumatic stress symptoms and attitude toward crisis mental health services among clinically stable patients with COVID-19 in China. Psychological medicine, 51(6), 1052-1053.

Cheng S, Wong C, Tsang J, Wong K. (2014). Psychological distress and negative appraisals in survivors of severe acute respiratory syndrome (SARS). Psychological Medicine, 34(7), 1187-1195.

Davazdah-emami M, Kharatzadh H, Mahaki B. (2019). Effectiveness of Mindfulness-based Stress Reduction on the Quality of Life of Patients with Type II Diabetes Mellitus. Journal Diabetes Nurs. 6(4):607-17. (In Persian)

Diaz-Silveira C, Alcover C, Burgos F, Marcos A, Santed A. (2020). Mindfulness versus Physical Exercise: Effects of Two Recovery Strategies on Mental Health, Stress and Immunoglobulin A during Lunch Breaks. A Randomized Controlled Trial. International joumal of environmental research and public health, 17(8), 2839.

Gaffari S. (2008). Investigation of the effect of progressive muscle relaxation technique on depression, anxiety and stress in patients with multiple sclerosis. 45-53. (In Persian)

Ghavidel S, Mosazadeh T. (2016). The effectiveness of metacognitive therapy based on faulty mindfulness in reducing anxiety, depression and perceived stress in infertile women. Second National Conference on Sustainable Development in Educational Sciences and Psychology, Social and Cultural Studies, Tehran. (In Persian)

Gross C, Kreitzer M, Reilly-Spong M, Wall M, Winbush N, Patterson R, Cramer-Bomemann M. (2011). Mindfulness-based stress reduction versus pharmacotherapy for chronic primary insomnia: a randomized controlled clinical trial. Explore, 7(2), 76-87.

Hita-Contreras F, Martinez-Lopez E, Latorre-Roman P, Garrido F, Santos M, artinez-Amat A. (2014). Reliability and validity of the Spanish version of the Pittsburgh Sleep Quality Index (PSQI) in patients with fibromyalgia. Rheumatology international, 34(7), 929-936.

Hong G, Kang H, Oh E, Park Y, Kim H. (2016). Reliability and validity of the Korean version of the perceived stress scale-10 (K-PSS-10) in older adults. Research in gerontological nursing, 9(1), 45-51.

Khosravi E, Ghorbani M. (2016). Effectiveness of mindfulness-based stress reduction on perceived stress and blood pressure among the hypertensive women. KAUMS Journal (FEYZ), 20(4), 361-368. (In Persian)

Koopman C, Classen C, Cardena E, Spiegel D. (2015). When disaster strikes, acute stress disorder may follow. Joumal of traumatic stress, 8(1), 29-46.

Kuhlman K, Robles T, Dooley L, Boyle C, Haydon M, Bower J. (2018). Within-subject associations between inflammation and features of depression: Using the flu vaccine as a mild inflammatory stimulus. Brain, behavior,and immunity, 69, 540-547.

Lee Y, Subramaniapillai M, Brietzke E, Mansur R, Ho R, Yim S, McIntyre R. (2018). Anti cytokine agents for anhedonia: targeting inflammation and the immune system to treat dimensional disturbances in depression. Therapeutic advances in psychopharmacology, 8(12), 337348.

Lima B, Hammadah M, Wilmot K, Pearce B, Shah A, Levantsevych O, Vaccarino V. (2019). Posttraumatic stress disorder is associated with enhanced interleukin-6 response to mental stress in subjects with a recent myocardial infarction. Brain, behavior, and immunity, 75, 26-33.

Liu K, Chen Y, Wu D, Lin R, Wang Z, Pan L. (2020). Effects of progressive muscle relaxation on anxiety and sleep quality in patients with COVID-19. Complementary therapies in clinical practice, 39, 101132.

Liu N, Zhang F, Wei C, Jia Y, Shang Z, Sun L, Liu W. (2020). Prevalence and predictors of PTSS during COVID-19 outbreak in China hardest- 
hit areas: Gender differences matter. Psychiatry research, 287, 112921.

Liu W, Zhang Q, Chen J, Xiang R, Son H, Shu S, Liu Y. (2020). Detection of Covid-19 in children in early January 2020 in Wuhan, China. New England Joumal of Medicine, 382(14), 13701371.

Lu H, Stratton C, Tang Y. (2020). Outbreak of pneumonia of unknown etiology in Wuhan, China: The mystery and the miracle. Journal of medical virology, 92(4), 401.

Mak I, Chu C, Pan P, Yiu M, Chan V. (2014). Longterm psychiatric morbidities among SARS survivors. General hospital psychiatry, 31(4), 318-326.

Ministry of Health of the Islamic Republic of Iran. (2021). (In Persian)

Monson E, Caron J, Mc Closkey K, Brunet A. (2017). Longitudinal analysis of quality of life across the trauma spectrum. Psychological Trauma: Theory, Research, Practice, and Policy, 9(5), 605.

Nameni E, Shirdel M, Jahangiri A. (2016). The study of effectiveness metacognitive techniques educationon life style of married women nurses in Bojnoord . Joumal of North Khorasan University of Medicine Science. 9 (1): 135-146. (In Persian)

Noone P, Flu G. (2013). Q-fever-related absence and PTSD in reservists. Occupational medicine, 63(4), 311-311.

North R. (2014). Molecular physiology of P2X receptors. Physiological reviews, 82(4), 10131067.

Rezayizadeh T. (2019). The Effectiveness of CognitiveMental Therapy Based on Mindfulness, Awareness of Perceived Stress, Intellectual Ruminant, and the Difficulty of Emotional Regulation in Women with Type 2 Diabetes (3-month follow-up). Iranian Joumal of Psychiatry and Clinical Psychology; 24.4:37083. (InPersian)

Sattarpour F, Ahmadi E, Sadegzadeh S. (2015). Effect of mindfulness training on reduction of depressive symptoms among students. Joumal of Gorgan University of Medical Sciences, 17(3), 81-88. (In Persian)

Steenblock C, Todorov V, Kanczkowski W, Eisenhofer G, Schedl A, Wong M, Bomstein S. (2020). Severe acute respiratory syndrome coronavinus 2 (SARS-CoV-2) and the neuroendocrine stress axis. Molecular psychiatry, 25(8), 1611-1617.

Van Hoek A, Underwood A, Jit M, Miller E, Edmunds W. (2011). The impact of pandemic influenza H1N1 on health-related quality of life: a prospective population based study. PloS one, 6(3), e17030.

Wells A, Fisher P, Myers S, Wheatley J, Patel T, Brewin C. (2009). Metacognitive therapy in recurrent and persistent depression: A multiple-baseline study of a new treatment. Cognitive therapy and research, 33(3), 291300.

Wells A, Matthews G. (2014). Attention and emotion (Classic edition): A clinical perspective. Psychology Press.

Wells A, Walton D, Lovell K, Proctor D. (2015). Metacognitive therapy versus prolonged exposure in adults with chronic post-traumatic stress disorder: A parallel randomized controlled trial. Cognitive Therapy and Research, 39(1), 70-80.

Wells A. (2011). Metacognitive therapy for anxiety and depression. Guilford press.

Wheaton M, Abramowitz J, Berman N, Fabricant L, Olatunji B. (2012). Psychological predictors of anxiety in response to the H1N1 (swine flu) pandemic. Cognitive Therapy and Research, 36(3), 210-218.

Wu K, Chan S, Ma T. (2015). Posttraumatic stress, anxiety, and depression in survivors of severe acute respiratory syndrome (SARS). Journal of Traumatic Stress: Official Publication of the International Society for Traumatic Stress Studies, 18(1), 39-42.

Xiang Y, Yang Y, Li W, Zhang L, Zhang Q, Cheung T, Ng C. (2020). Timely mental health care for the 2019 novel coronavinus outbreak is urgently needed. The lancet psychiatry, 7(3), 228-229. 
Xie L, Deng Y,Zhang J, Richmond C, Tang Y, Zhou J. (2016). Effects of progressive muscle relaxation intervention in extremity fracture surgery patients. Westem joumal of nursing research, 38(2), 155-168.

Yook K, Lee S, Ryu M, Kim K, Choi T, Suh S, Kim J. (2011). Usefulness of mindfulness-based cognitive therapy for treating insomnia in patients with anxiety disorders: a pilot study. The Joumal of nervous and mental disease, 196(6), 501-503.

Zhang J, Liu X, Xie X, Zhao D, Shan M, Zhang X, Cui H. (2015). Mindfulness-based stress reduction for chronic insomnia in adults older than 75 years: a randomized, controlled, single-blind clinical trial. Explore, 11(3), 180-185. 